\title{
UNIVERSAL HUMAN RIGHTS DECLARATION: RIGHT TO RETURN OF PALESTINIAN REFUGEES
}

\author{
Summer Sultana* \\ Sabir Ijaz ${ }^{* *}$ \\ Mubasshar Hassan Jafri ${ }^{* * *}$
}

\begin{abstract}
For over last 70 years, the concept of "return" attained primary focus for the national narrative of Palestinian struggle against devastating conditions, categorized as (i) eviction from ancestral homeland, (ii) diffusion in all aspects and (iii) reconstitution of national unity. However, the very idea create fears among Israelis regarding their authority of whole Zionist enterprise, as well as demographic stability of Arab-Jewish ventures, with regards to the return of large number of Palestinians to their own places or any other part in Palestine. Discrimination in opposition to Palestinians is no longer perpetrated fully by Israeli state, but common to its society, as well. Our article is an answer to the complicated question: Can refugees along with other displaced victims ever claim their right in entering Israel and Palestine, since this State includes Gaza and West Bank territories? Various articles have made an attempt to clarify the matter through some internal laws and have also interpreted the rights mentioned in 'International Covenants on Civil and Political Rights', particularly while clarifying the idea evolved from the typical term: 'his own country'. The article focuses on the viable first point, specifically on the claim as a right of the Diasporas return to the formerly called 'Palestine'. Various resources are utilised for the purpose of the research. This includes books, scholarly researched articles and newspapers etc. The study is analytical in nature and based on qualitative research method. Most of the literature used for the article is Secondary. The conclusion drawn in precise manner is that the intentions are blended in repeated violations of human rights, along with ethnic and religious refining and various innumerable deficiencies, and try to become regularly involved in sensitive issues. This turned out to be disheartening for the people living there as no efforts are made for a truthful resolution.
\end{abstract}

Keywords: Human rights; international law; violation refugees; UNRWA

\section{Introduction}

\section{Brief History of the Problems of Palestinian Refugees}

Palestine and its inhabitants comprising of Muslims, Christians and Jews were under Ottoman rule for over five centuries. Eventually when the Turks were trounced by the end of WWI, the British rulers occupied Palestine. The League of Nations signed a Treaty to hand over Palestine for administrative control to Great Britain from 1918 to

\footnotetext{
* Summer Sultana, Ph.D. Professor \& Chairperson, Department of Political Science, University of Karachi ${ }^{* *}$ Sabir Ijaz, Ph.D.Scholar, Department of Political Science, University of Karachi

**** Mubasshar Hassan Jafri, Ph.D.Scholar, Center for International Peace and Stability (CIPS) NUST
} 
1922. The British Mandate led towards eruption of violence among Jewish and Arab populations, due to patriotic and national instincts of both nations and rapidly growing Jewish immigration on Arab lands ${ }^{1}$.

The commitment of international community towards international laws pertinent to human rights within the context of Palestine, it is quite important to understand why and how this matter was put up on agenda of United Nations Organizations (UNO)? This is a confusing question because it had usually been resolved in political terms rather than through agreed norms of international laws. The UN was formulated in 1945, whereas the Palestinian issue dates back to even much longer times. They were denied their fundamental human rights, particularly those pertaining to self-determination and given the category of second-class citizens internationally. Moreover, the Zionist Movement (modern day Israel) refused religious, historical and political claims of the majority of inhabitants to govern Palestine. Their rights to 'self-determination' and 'Return' were completely denied ${ }^{2,3}$.

\section{Literature Review}

There is an abundance of literature available on Palestinian refugees. Much of the existing literature focuses on status of Palestinian refugees and conflict between Palestine and Israel. Very little has been written on Palestinian right of return according to international law. This article fills this gap by focusing and including literature on right of return of Palestinian refugees to their homeland according to International Law and Universal Human Rights Declaration.

\section{Status of Palestinian Refugees}

In order to define a 'Palestinian refugee', we apparently present it as follows: "any person having initial and original residence in Palestine for at least two years, before the conflicts of 1948, and therein losing his residence as well as his source of earnings". He takes protection in a country which provides relief and shelter, viz. United Nations Relief and Works Agency (UNRWA). A refugee and his direct descendant(s) falling within this definition are eligible for all assistance provided by the Agency, provided they acquire its registration and reside within its operational $\operatorname{area}^{4}$. Any Palestinian, who was once expelled, fled away, sent in forced exile from home in the vicinity of historical Palestine or refused re-entry after having traveled overseas at any time during the year of conflict (1948) and present day, falls within this category.

\footnotetext{
${ }^{1}$ Kassim, Anis. F. "Legal Systems and Developments in Palestine." Palatine Yearbook of International Law 1, no. 1 (1984).

${ }^{2}$ AFSC. Palestinian Refugees and the Right of Return. 2010. https://www.afsc.org/resource/palestinianrefugees-and-right-return (accessed December 6, 2018).

${ }^{3}$ Kramer, Tanya. "The Controversy of a Palestinian”Right of Return to Israel." Arizona Journal of International and Comparative Law 18, no. 3 (2001): 979-1016.

${ }^{4}$ Peretz, Don. Palestinians, Refugees, and the Middle East Peace Process. Washington, D.C: US Institute of Peace Press, 1993. 11-12.
} 
The number of Palestinian refugees currently is over seven million people ${ }^{5}$. The largest group comprises of those refugees who were forced to flee or thrown out during the historic break up of Palestine state in 1948. Nearly 5 million of them have acquired registration with UNRWA, as mentioned in 2014. Similarly, about one million are additionally included, who had been displaced in 1948, but are no longer registered with UNRWA for assistance in relief and shelter ${ }^{6}$.

To mention the second group with highest number of refugees is pertinent to those Palestinians (about one million), who fled or were thrown away, for the first time in 1967. Surprisingly, $1 / 3^{\text {rd }}$ consisted of Palestinians compelled to flee during 1948 and 1967 from their villages and had to abandon their properties. Although this group is no longer allowed to return, but are currently staying either in Israel or occupied Palestinian territories. Presently, nearly 350,000 of them reside inside published Israeli borders and also possessing its citizenship. Nonetheless, they are disallowed now to go back to their place of origin from where they had fled away in 1948. An additional number of 130,000 Palestinians had been internally displaced in occupied territory due to the War of $1967^{7}$.

We have no account about the exact number of Palestinians expelled or refused to return due to the effect of 1967 war. The human beings, who had invalidated their cards of identification and failed to acquire the rights of residency, denied reunification with their families, deported or exiled earlier. Such practices continued in occupied Palestinian territory and Israel, through various approaches, like confiscation of land, forceful displacement, demolition of homes, and revocation of residency rights ${ }^{8}$.

\section{Palestinian Refugees Camps Located Elsewhere}

A large number of Palestinian refugees are residents of occupied Palestinian land or adjoining areas. Among the registered UNRWA refugees, those living in Jordan and Gaza comprise of nearly 2 million (over 40 percent) and one million (nearly 23 percent), respectively and whereas nearly 16 percent $(760,000)$ reside on the West Bank and 462,000 stay in Syria. Accordingly, an approximated number of 420,000 refugees are in Lebanon ${ }^{9}$. Surprisingly, two refugees who are still not registered with UNRWA are living in international locations around the globe, whereas large population groups are positioned safely in Egypt, Jordan, Chile, Saudi Arabia, Gulf States, and the United States of America ${ }^{10}$.

\footnotetext{
${ }^{5}$ Chen, Tianshe. "Palestinian Refugees in Arab Countries and Their Impacts." Journal of Middle Eastern and Islamic Studies (in Asia) 3, no. 3 (2009): 42-56.

${ }^{6}$ Yin, Gang. Arab-Israeli Conflict: Problems and Way Out. (Beijing: International Cultural Press, 2002), 309310

${ }^{7}$ Badil. Survey of Palestinian Refugees and Internally Displaced Persons (2008-2009). July 12, 2009. https://www.badil.org/phocadownload/Badil_docs/publications/survey08-09/survey08-09-executivesummary.pdf (accessed 2018).

${ }^{8}$ Khalidi, Walid. "Plan Dalet: Master Plan for the Conquest of Palestine." The Journal of Palestine Studies 18, no. 1 (1988): 4-33.

${ }^{9}$ Badil. Survey of Palestinian Refugees and Internally Displaced Persons (2008-2009).

${ }^{10}$ Henri, Rueff, and Viaro Alain. Palestinian Refugee Camps: From Shelter to Habitat. 2010.

http://doc.rero.ch/record/302490/files/hdp041.pdf (accessed July 12, 2018).
} 
Consequently, still non-registered UNRWA Palestinian refugees generally tend to acquire immigrant, citizenship, or attain reputation as temporary inhabitant in any international location. Their popularity in prison is generally stable and constantly reputed with different human beings retaining same status as prisoners in the country of residency. The refugees residing with UNRWA in Syria, Lebanon, and Jordan have even greater significant and better popularity. Almost 95 percent of total refugees in Jordan attained citizenships, which helps them to become eligible to contribute in its various political and economic activities. Additionally, most of the UNRWA registered refugees (over 80 percent) do not any longer stay within UNRWA run 10 camps, allocated in Jordan ${ }^{11}$.

On the contrary, Lebanese government has severe limitations on almost all Palestinian refugees and they are restricted to remain within UNRWA camps. These refugees have not been provided Lebanese citizenship and are surprisingly, still treated as aliens. Even political as well as social rights are not provided to these refugees. They are denied offerings in admissions in publicly-run authorities, like healthcare, education, social security, etc. The UNRWA acts as the only essential authority to issue such offerings in Lebanon. The Palestinian refugees do not have the right to acquire jobs in many typical professions $^{12}$.

The Palestinian refugees in Syria are very well accepted to be included into Syrian society, besides being allowed to enter into various employments and government services, as well. These activities were made common before the latest Syrian civil war. Surprisingly, the refugees have not been allowed Syrian citizenship, or the right to own excess property. It is noteworthy that many refugees in Syria were dislocated because of the Syrian conflict and suffered collectively along with many Syrians. Refugees living in occupied Palestinian territory in Syria face similar scenario with same boundaries on their rights as are the apparent challenges in case of all other Palestinian refugees ${ }^{13}$.

\section{Primary Causes of Displacement of Palestinians}

Although it is claimed as an accepted and regularly continuous fact that Palestinians, on the first stance, voluntarily left their homeland in 1948and more significantly, as a second viewpoint with the willingness and motivational attitude of Arab leaders, but such claims are no longer acceptable, nor supported by any historical evidence recorded so far. It is apparently evident that huge masses of nearly 750,000 Palestinians were displaced and forced to flee from their place of origin due to direct and targeted aggression and unbearable threats even on their lives. The Israeli forces blocked the ways of return of many Palestinians who tried to return during or after the end of various conflicts and warfare $^{14,15}$.

\footnotetext{
${ }^{11}$ Dowling, Paddy. Jordan's Palestinian refugee camps. 2018. https://www.independent.co.uk/news/world/middle-east/jordan-palestine-refugee-camps-photographya8341826.html (accessed July 12, 2018).

${ }^{12}$ Boling, Gail J. Palestinian Refugees and the Right of Return: An International Law Analysis. 2001.

https://www.badil.org/phocadownload/Badil_docs/bulletins-and-briefs/Brief-No.8.pdf (accessed July 12, 2018).

${ }^{13}$ Sirhan, Bassem. Palestinian Refugee Camp Life in Lebanon. 1974. http://www.palestine-

studies.org/jps/fulltext/38366 (accessed July 12, 2018).

${ }^{14}$ Khalidi, Walid. "Plan Dalet", Op.cit. 6-7.
} 
Their systematic dislocations started out well before UN Partition Plan, which came into formal enforcement on $15^{\text {th }}$ May 1948, marking the actual date of start of formal conflicts among Israeli army and surrounding Arab forces. Although very aggressive enmities and fierce hostilities had started by end of 1947 with restricted warfare aggressions and continuously went on till May 1948. It was an insistent conflict among un trained Palestinian forces and well-prepared Jewish army, including the Hagganah, Irgun, and Palmach $^{16}$.

The Jewish forces started on $15^{\text {th }}$ February 1948 for the first time, to absolutely depopulate all residents of Barrat Qisarya, Qisarya, Atlit and Khirbat Al-Burj along with various other villages (near present day Cesarea). This action and planned practice of the Jewish forces dramatically changed the nature of their conflicts. The government coverage was all set and finalized by March 1948to be executed through "Plan Dalet", by Jewish leadership accordingly ${ }^{17}$.

\section{Research Methodology}

Various resources will be utilized for the purpose of the research. This will include books, scholarly researched articles and newspapers etc. The study would be analytical based on qualitative research method. Most of the literature used for the article is secondary. It would include scholarly journals and books on history of Palestinian refugees, status of Palestinian refugees, Palestinian right of return, Israeli perspective on right of return and the right to return for Palestinian refugees in international law. Study has included reports of United Nations Relief and Works Agency(UNRWA), United Nations (UN), UN Charter, Resolutions of Security Council and Universal Declaration of Human Rights on Palestinian right of return. Research articles like Palestinian Refugees and the Right of Return: An International by Gail J. Boling (2001), Palestinian Refugees in Arab Countries and Their Impacts by Tianshe Chen (2009), Plan Dalet: Master Plan for the Conquest of Palestine by Walid Khalidi (1988) have been included in the study to understand Palestinian refugees' right of return according to International Law. Books like The Oslo Accords: International Law and the Israeli-Palestinian Peace Agreements by Geoffrey R. Watson (2000) and Arab-Israeli Conflict: Problems and Way Out by Yin (2002) have also been viewed to look into the Palestinian right of return.

\section{Is Right to Return a Legal Right?}

Various problems determined with reference to Palestinian refugees presents very extraordinary and comprehensive description as follows:

...one of the most intractable and a focal point in the conflict between Israel and its Arab neighbors.

However, accurate return is a cornerstone of Palestinian struggle, and assumed as their principle motto to be unassailable as right to return towards their original motherland.

${ }^{15}$ Pappe, Ilan. The Ethnic Cleansing of Palestine. (London: Oneworld Publication, 2006).

${ }^{16}$ Badil. Survey of Palestinian Refugees and Internally Displaced Persons (2008-2009).

${ }^{17}$ Khalidi, Walid. Op.cit. 
These groups comprised of refugees, including their descendants, who had fled away voluntarily or forced to flee, during both conflicts of 1948 and $1967^{18}$.

The right to return has now been accepted in its true spirit as a legal law internationally. UN General Assembly's Resolution \# 194 was adopted in December 1948, which stood quite popular among the Palestinian refugees, since it is pertinent to their right to return to their homes. The Security Council of UN handed over another Resolution (\#237) to Israel in June 1967. The Resolution called on Israeli state to act as a facilitator in the process of return of refugees. Since Israel had seized land few days earlier continued to violate its responsibility under worldwide law. It showed no intentions of clearing or amending its previous historical unjustified deeds, which had created the matter pertaining to Palestinian refugees. The right to return had been considered as one of the most leading issue which prevented a viable solution and justified resolution of the differences accordingly. In any of the scenarios and particularly in the context of Palestinian statehood matters, Israel never even considered the right of return as a problematic question ${ }^{19}$.

Although the number of authentic refugees of 1948is declining but their descendants are widely increasing and currently their number is greater than 6 million. Even if a fraction of the population had accepted and executed this right, the stability of political structure in Israel could have potentially been upset towards very drastic situations. Israelis have at length received strict admonition of "demographic threats" but the challenges of entire "Jewish state" rely on stabilizing demographic authority and control. Their unwillingness to take delivery of the right to return is not to be taken as a surprise.

\section{Israeli Perspectives on Right to Return}

As an outcome of United Nations resolution adopted on November 29, 1947, resulted in the division of Palestine created two separate states (Jewish Arab and Palestinian Arab). The decision sparked up a coordinated attack by joint armies of neighboring Arab states on the Jewish community in Palestine. The up-coming war and state of Israel's establishment was the turning point for the materialization of innumerable refugees in May 1948. With the announcement of ceasefire in 1949, nearly half million Palestinians along with same number of Jews had to leave voluntarily or were forced to leave to seek refuge in recently formed Jewish Arab state. To precisely mention some specific reasons for leaving their homeland in such large numbers and examine this influx of refugees became a matter of severe importance and were consequently considered as the most critical intense debate in history. The parties themselves, other stakeholders and even contemporary scholars and researchers disagree with the point whether the refugees left voluntarily or were compelled to do so by the consent of their own leaders and thrown

\footnotetext{
${ }^{18}$ Lawand, K. "The Right to Return of Palestinians in International Law." International Journal of Refugee Law 8, no. 4 (1996): 532-568.

${ }^{19}$ Khalidi, Walid. “Observations on the Right of Return.” Journal of Palestine Studies 21, no. 2 (1992): 29-40.
} 
out with various actions of opposition, or considered as a combination of all these factors $^{20}$.

In order to acquire the most suitable solution and best resolution for the "refugee problems", Israeli and Arab leaderships had been in conflict for decades and are still struggling on this matter. From the official viewpoint evolved over time by Palestinians points out towards the right to return of refugees to their homeland, provide reasonable payments for losses and/or damages for properties and may also be compensated morally for sufferings inflicted over them, during the past half a century. Palestinians also believed that issues of refugees' right of return must be settled, irrespective of any final determined or motivational decisions of Arab-Israeli differences.

On the contrary, official version of Israeli community was subjected to their intentions and plans and had not even changed slightly, since the ceasefire in1949. Their arguments stated that refugees could return to Israel but in very limited number and not to their original houses because most of these may have been completely damaged or ruined. Moreover, the Israelis also argued that remaining refugees may be allowed to "return" to Palestinian-controlled areas or opt to be rehabilitated within their present state of residence. They also demanded to compensate each and every refugee, whether they are from Jewish or Arabic state. Showing some reasonable contrast to Palestinian viewpoint, Israelis believed that issues pertaining to return of refugees should be resolved with permanent solution to their conflicts ${ }^{21}$.

The earliest General Assembly Resolution \# 194 of United Nations Organizations on this matter was adopted in December 1948, setting out an alternative for Palestinian refugees, as follows:

The refugees wishing to return to their homes and live at peace with their neighbors should be permitted to do so at the earliest practical date; compensation should be paid for the property of those choosing not to return and for loss of or damage to property which, under principles of international law or in equity, should be made good by the Governments or authorities responsible for such matters 22,23 .

The legal status of Resolution \# 194 and its impact in the political context is now being discussed at length, but surprisingly, apparently we find no specific definition of the typical phrase "right of return", for our evidence in any relevant text. Even more surprisingly, we are shocked to see that there is no declaration, specifically mentioned, which is pertinent to this phrase, in vital and imperative UN Security Council resolutions numbered as 242 and 338, regarding Israeli-Palestinian struggle. Subsequently and additionally, this typical phrase is not pointed out in the Camp David Peace Accord of

\footnotetext{
${ }^{20}$ Kalman, Matthew. The Palestinian Right of Returnin in International Law - The Israeli Perspective. 2017. https://prrn.mcgill.ca/research/papers/matthewkalman.pdf (accessed December 5, 2018).

${ }^{21}$ Lapidoth, Ruth. Legal Aspects of the Palestinian Refugee Question. 2002. http://www.jcpa.org/j//vp485.htm (accessed July 12, 2018).

${ }^{22}$ Kalman, Matthew. The Palestinian Right of Returnin in International Law - The Israeli Perspective. 2017.

${ }^{23}$ Lapidoth, Ruth. Legal Aspects of the Palestinian Refugee Question. 2002.
} 
$1978^{24}$. This Accord was signed by Israel and Egypt for processing of peace in the region. Various other Peace Accords (popularly known as Oslo Accords), adopted and signed by Israel and PLO (Palestinian Liberation Organization) in 1993, do not slightly indicate 'right of return' therein. Similarly, Peace Treaty (1994) made by Israel and Jordan also showed similar trends. However, Israel agreed in both(Oslo Accords and Treaties signed with Egypt and Jordan) to negotiate on the refugee problems while discussing the talks on Palestine-Israel 'final status",25.

Although the wordings of Peace Agreement (since 1978) signed between Israel and its neighboring territories apparently suggests finding compromising solutions for the Palestinian refugees. Similarly, Israel admitted to mutually establish a multi-lateral Refugee Working Group during Madrid Peace Conference (1991), under the chairmanship of Canadian authorities. The main reason to establish the multi-lateral working group was to ease the hardships of Palestinian refugees, until such time when long term better results were deduced. Israeli leaders with vast expertise and experience of legal affair shad recognized that the matters related to Palestinian refugees need viable resolution on urgent basis now, since they established a firm belief that "right to return" has no basis in international laws for a remedy or relief for Palestinian refugees. They had time and again only demanded for a permanent settlement of the conflicts among Israeli and Palestinian communities ${ }^{26}$.

Professor Emeritus of International Law at the Hebrew University in Jerusalem, Ruth Lapidot has very convincingly summed up the legal view point of the Israeli community in the statement, as follows:

Neither under the general international conventions, nor under the major U.N. resolutions, nor under the relevant agreements between the parties, do the Palestinian refugees have a right to return to Israel ${ }^{27}$.

\section{The Right to Return for Palestinian Refugees in International Law}

While entering the long and continued remembrance (70 years) of 'Nakba' (catastrophes) to refugees and descendants of struggling Palestinians have, nonetheless failed to resolve their crises. Surprisingly, this is the biggest and longest-overdue pending issue in the world, comprising of 7.54 million refugees, along with720,000 locally and internally displaced victims. To be more precise, nearly two groups consisting of 5.3 million refugees, each being registered with United Nations Relief and Works Agency(UNRWA) and 1.5 million are found to be residing in 58-refugee camps established across Syria, Lebanon, and Jordan and Gaza, West Bank and East Jerusalem, which form the part of some occupied Palestinian territory. Palestinian refugees displaced forcibly during 1948

\footnotetext{
${ }^{24}$ John Cabot University. The Recognition of an Independent Palestinian State. 2012. https://www.johncabot.edu/.../jcumun\%20general\%20assembly\%20study\%20guide.do (accessed December 9, 2018).

${ }^{25}$ Security Council Report. Security Council Official Records. 1979. https://www.securitycouncilreport.org/wpcontent/uploads/Chap\%20VII\%20SPV\%202157.pdf (accessed December 7, 2018).

${ }^{26}$ Kalman, Matthew. The Palestinian Right of Returnin in International Law - The Israeli Perspective. 2017.

${ }^{27}$ Lapidoth, Ruth. Legal Aspects of the Palestinian Refugee Question. 2002.
} 
and 1967 wars, are facing huge and unavoidable challenges since UN-mandated 'Right of Return' had not been fully implemented accordingly ${ }^{28,29}$.

We assume very rightly with confidence that the 'Right of Return' is universally identified, presented and adopted in various legal aspects, like Global Refugees Law, Human Rights Law, Laws of Nationality, and Laws of Country Responsible for their Rehabilitation. Moreover, it is also given in the Universal Declaration of Human Rights (Article 13) that nearly all major treaties, intended to protect the rights of refugees during armed conflicts. Various resolutions are also executed under humanitarian laws in very important and central human rights conventions pertaining to the obligations and duties of governing states ${ }^{30}$. Such legal and justified rulings are consistently referred to in UN resolutions, as well. The law of 'Right of Return' was very well accepted and attained a well-known impetus in 1948. The Resolution \# 194(III) of UN General Assembly affirmed their rights to return to their native motherland, gain restitution and provide compensation for confiscated and lost properties. For a stable consistency in Resolution \# 194, UN reaffirmed it for more than 135 times, which had never been done earlier in the history of UN with regards to worldwide laws and units. In a similar and identical spirit, Resolution \# 2535 also intended to find out the reasons which created the disturbances among the refugees. There is very clear evidence that denial of their unchallengeable rights under UN Charter and Universal Declaration of Human Rights led towards complications in the matter ${ }^{31}$.

It is also a noteworthy point that many other determined and adopted UN resolutions, like 393, 2452 and 3236, supported comprehensively the 'Right of Return' as being "indispensable for the answer of the query of Palestine". Since Israel had paid no heed in executing UN resolutions and for other obvious reasons, Israel's membership to UN was subjected with its implementation of resolution \# 194. The Israeli government felt that if the resolution is implemented, then its compliance would demoralize the Jewish characteristics of Israel ${ }^{32}$.

The consent of Israeli attitude to incline towards conventions, its obligations in the direction of prisons stands parallel with international laws and strongly supports Palestinian refugees. But precisely, International Convention on Civil and Political Rights (ICCPR) affirms lawful right within a territory for to move freely around and prefer to choose any place for residential purposes. Every individual has the right to live in or leave any country, which also includes his own country. These basic rights mentioned above are unconditional and carry no restrictions, except those provided legally including the protection of national security, public orders, public health and moral behaviors or respect the rights and freedom of others. These legal aspects are considered to be

${ }^{28}$ Henri, Rueff, and Viaro Alain. Palestinian Refugee Camps: From Shelter to Habitat. 2010.

${ }^{29}$ Kramer, Tanya. "The Controversy of a Palestinian"Right of Return to Israel." Arizona Journal of International and Comparative Law 18, no. 3 (2001): 979-1016.

${ }^{30}$ Lawand, K. "The Right to Return of Palestinians in International Law."

${ }^{31}$ Rempel, Terry M. The United Nations Conciliation Commission for Palestine, Protection, and a Durable Solution for Palestinian Refugees. 2000. http://badil.org/phocadownload/Badil_docs/bulletins-and-briefs/BriefNo.5.pdf (accessed July 12, 2018).

${ }^{32}$ Boling, Gail J. Palestinian Refugees and the Right of Return: An International Law Analysis. 2001. 
consistent with other legal rights, which are recognized and adopted in the present Covenant, which states that: "No one shall be arbitrarily deprived or disadvantaged of the right to enter his own country" (Article 12) of $\mathrm{OHCHR}^{33}$.

Similarly, it is apparent from the International Convention on the Elimination of All Forms of Racial Discriminations (CERD) clearly mention that State Parties must undertake the prohibition process to remove all racial discriminations apparent in any type of inhuman aspects. Also, the rights of every individual must be guaranteed, with elimination of racial discrimination in caste, creed and other factors. Keeping in view the equality of each individual before the law, execution is notably important for all basic rights and those determined in Article 5 of $\mathrm{OHCHR}^{34}$.

Furthermore, Refugee Convention's Resolution (Article 1-D) is directly applied exclusively to Palestinian refugees and also assigns full safety in every respect. All major assistance for this purpose is acquired from two different international agencies, viz. United Nations Conciliation Commission on Palestine (UNCCP) in association with UNRWA, mutually agreed-upon viable and long-lasting solution provided in Resolution $\# 194^{35}$.

Keeping in view various global regulations it is completely unlawful to deny refugees of a particular and precise race, creed, color, caste, national or ethnic origin, and their right to return to native places ${ }^{36}$. Some unwanted Israeli laws are intended to bar the return of Palestinian refugees. Consequently, some examples pertaining to illegal laws practiced in Israel are presented here. Within the purview of 'Law of Return', Israel has occupied many Palestinian territories. Again, opposing the 'Nationality Law', Israel sanctions legal points directly focused on Palestinian refugees for mass denationalization ${ }^{37}$. Similarly, Israel also captured Palestinian private properties and confiscated many land-holdings, contrary to the 'Absentee Property Law and Land Acquisition Law', while the Right of Return is considered to be the main and important remedy for Palestinian refugees to become entitled for compensation for their original homes and confiscated properties. This demand is totally attributed to the UN Principles and Guidelines (ICCPR) stated in Article 2, and other similar legal instruments. Hence, these compensating aspects (including right to return) are also provided for rehabilitation, inner satisfaction of

${ }^{33}$ OHCHR. International Convention on the Elimination of All Forms of Racial Discrimination. 1969. https://www.ohchr.org/en/professionalinterest/pages/cerd.aspx (accessed July 12, 2018).

${ }^{34}$ Ibid.

${ }^{35}$ UNHCR. Convention and Protocol Relating to the Status of Refugees. 1967.

https://cms.emergency.unhcr.org/documents/11982/55726/Convention+relating+to+the+Status+of+Refugees+ $\% 28$ signed+28+July+1951\%2C+entered+into+force+22+April+1954\%29+189+UNTS+150+and+Protocol+rel ating+to+the+Status+of+Refugees+\%28signed+31+January+1967\%2C+ent (accessed July 12, 2018).

${ }^{36}$ Sayej, Loureen. Palestinian Refugees and the Right of Return in International Law. 2018.

http://ohrh.law.ox.ac.uk/palestinian-refugees-and-the-right-of-return-in-international-law/ (accessed December $8,2018)$

${ }^{37}$ OHCHR. Israeli settlements in the Occupied Palestinian Territory including East Jerusalem, and the occupied Syrian Golan. 2017. https://www.un.org/unispal/document/ga-resolution-on-israeli-settlements-in-theoccupied-palestinian-territory-including-east-jerusalem-and-the-occupied-syrian-golan/ (accessed December 7, 2018). 
victims, and guarantee of not repeating such activities to Palestinian refugees, but were time and again, denied to the present times ${ }^{38}$.

Notwithstanding the persevering with inactiveness in global community, the legal aspect of Right of Return still remains an unchallengeable and requisite ordinary obligation, which must be equally applied on the Palestinian people. Obviously, it no longer needs to be reliant on political influence and moral aspects. Being an individual and collective proper that is fundamentally linked with exercising the rights to self-determination adequately to all 13 million Palestinians world-wide is legally executed. However, it is one and only legal right, which is currently not being given due status and respect. Until the Right of Return is not implemented in its true spirit, the human beings in Palestine would not be covered or be kept away from similar displacements and expulsion from homeland ${ }^{39}$.

When the United Nations Partition Plan was eventually implemented in a formal manner on May 15, 1948, Palestinians numbering between 250,000 and 300,000 had already faced expulsion from their original homes and native communities. It is worth a mention that most of the population included fundamental communities of Palestine, such as Safed, Haifa, Acre, and Jaffa ${ }^{40}$. The number of Palestinian population that lived in the area characterized an exact figure for various institutions in Israel were executed through United Nations Partition Plan. After15 ${ }^{\text {th }}$ May, 1948 the War was further extended, providing opportunities to Israeli forces to capture those areas, which were being established earlier to be part of Palestinian nation through the UN Partition Plan. Before the war could come to an end, about 750,000 Palestinians turned into destitute refugees, whereas nearly 500 to 600 of their villages were depopulated and later shattered to ruins ${ }^{41}$.

\section{Findings}

\section{Reasons for Disallowing Palestinian Refugees to Return Home}

With the displacement of Palestinians in 1948, they could obviously not be permitted to go back to their place of origin. The reasons traced historically lead us to know the actual facts. The Jewish community gradually assumed that the presence of Palestinians in the region was considered as a threat towards the protection and sustainability of majority in demographic sector in newly constituted Jewish kingdom. The view point in this regard was comprehensively made very clear during an assembly session with AFSC, held on August 9, 1949. The participants of this meeting included Don Stevenson and Eliahu

${ }^{38}$ Bracka. Past the Point of No Return? The Palestinian Right of Return in International Human Rights Law. 2005. https://law.unimelb.edu.au/_data/assets/pdf_file/0005/1681169/Bracka.pdf (accessed December 9, 2018).

${ }^{39}$ Khalidi, Walid. "Plan Dalet: Master Plan for the Conquest of Palestine."

${ }_{40}$ Alarby. Israel's destruction of Palestinian village is 'war crime': Amnesty. 2018. https://www.alaraby.co.uk/english/news/2018/9/7/israels-destruction-of-palestinian-village-is-war-crimeamnesty (accessed December 7, 2018).

${ }^{41}$ Zonsheine, David. Israel is about to destroy this Palestinian village. Will Britain step in? 2018. https://www.theguardian.com/commentisfree/2018/jun/14/israel-destroy-palestinian-village-khan-alahmar (accessed December 23, 2018). 
Elath, the former being an employee of AFSC and, the latter was the Israeli Ambassador to the United States. During the course of the meeting Stevenson asked Ambassador Elath whether Israel would be willing to receive Palestinian refugees if they return to their homes. The Ambassador negated the proposal and bluntly refused in the negative with following comment:

Israel would not do so keeping in view of the fact that it would be a suicidal commitment if Israel agrees to this suggestion ${ }^{42}$.

If we intensely explore the facts regarding the above comment, we conclude as a firsthand perception that the intentions of UN Partition Plan were to formulate a new state without standing characteristics of Jewish splendor and portray their remarkable economic and political structure. Without the expulsion of Palestinian population that once cherished in this region, and forced to leave their homelands, aggravated to pave the road for the creation of a Jewish State. It would neither have been viably possible nor practically feasible for the Jews with a slim majority (55 percent) as against 45 percent Palestinians to forcibly set up their state, without forcing the other side out of the region. Additionally and more surprisingly, land set aside for new Jewish kingdom was very widespread, whereas Israel had less than $10 \%$ of its own. To be more precise, Jews had been clearly and apparently proven to be in minority demographically in each northern (Eastern Galilee) and southern (Negev) sectors. The forthcoming new proposed state constituted approximately 30 percent (Palestinians) and 1 percent (Jews) within that area. Jewish assumed that their populace had sole majority once in coastal sections, but actually 65 percent of its population was placed in two cities of Tel Aviv and Haifa. This determined that Palestinians were in majority in nearly all regions accumulated and set aside to form a new Jewish State ${ }^{43}$.

For obvious reasons, had the newly set up of Israeli nation made sincere attempts to preserve the territory, which at some time in 1948 War had forcibly captured whilst additionally allowing displaced human beings during the 1948 conflicts struggled to return homewards, then accordingly Jewish population of new state would have shown them to be in the minority status. Israel's choice in stopping the return of Palestinians back towards their homes and properties at one time had not encouraged them now. They attempted to use aggression to discourage return of Palestinians refugees. However, focus of the Israeli government was towards some substitute to allow return of Palestinian refugees would strengthen their population and in turn, Israel would be forced to form binational kingdom with Jewish in minority status. Had the original Palestinian natives not been expelled from their homeland, the state of Israel would never had ever-emerged as a Jewish kingdom.

\section{Do Palestinians have the Right to Return?}

The comprehensive global laws pertaining to resettlement of Palestinian refugees in accordance with UN resolution with reference to 'right to return', has gained a very hot

${ }^{42}$ Chen, Tianshe. "Palestinian Refugees in Arab Countries and Their Impacts."

${ }^{43}$ Khalidi, Walid. "Revisiting the UNGA Partition Resolution." The Journal of Palestine Studies 27, no. 1 (1997): 5-21. 
discussion. Accordingly, all arrangements are well set for the return of displaced and destitute refugees to their native and real homeland. The first available source regarding the claims for legal support in this matter are mentioned clearly in UN General Assembly's Resolution\# 194 (III), para 11, adopted in its meeting held in the last month of 1948. The UN General Assembly resolved as follows:

The refugees wishing to return to their properties and stay at peace with their neighbors need to be authorized to do so at the earliest practicable date, and that compensation ought to be paid for the property of these choosing now, not to return and for loss of or damage to property which, below principles of global law or in equity, ought to be made top by way of the governments or authorities responsible; Instructs the Conciliation Commission to facilitate the repatriation, resettlement and monetary and social rehabilitation of the refugees and the fee of compensation $^{44,45}$.

The firmly placed rights are presented in details in the above resolution. Keeping in view various aspects of international rights, the resolution was adopted on humanitarian grounds, refugee laws, free will rights, etc. Similarly, through the Executive Conclusion No. 40 adopted another law of United Nations High Commission for Refugees (UNHCR). It categorically stated that:

The simple rights of individuals to return voluntarily to their use of a foundation are reaffirmed and it is advised that worldwide cooperation be aimed at achieving this solution ${ }^{46}$.

The comprehensive explanation of UNHCR's guide with regards to 'right of return' is exclusively perceptional, well-established and well-known for being considered as recognized norms of global regulations. Because of its international recognition, the right to return is being adopted and protected by many international organizations and agencies. To name some of these authorities, we would like to mention International Covenant on Civil and Political Rights, Fourth Geneva Convention, International Convention on the Elimination of All Forms of Racial Discrimination, Universal Declaration of Human Rights, etc ${ }^{47}$.

It is an obvious fact that many international treaties and accords covering human rights laws, which refer to freedom in speech, elimination of racial discrimination, free movements anywhere, etc. which also includes right to return ${ }^{48}$.

Moreover, Stig Jagers kiold attempts to provide evidence that 'right to return' or 'right to enter one's own country', was rightly adopted. A thorough resolution was executed

${ }^{44}$ UNRWA. General Assembly Resolution 194. 2010. https://www.unrwa.org/who-we-are?tid=85 (accessed July 12, 2018).

${ }^{45}$ Brynen, Rex. "Compensation for Palestinian Refugees: Law, Politics and Praxis." Israel Law Review 51, no. 1 (2018): 29-46.

${ }^{46}$ UNHCR. Voluntary Repatriation Voluntary Repatriation. 1985.

http://www.unhcr.org/excom/exconc/3ae68c9518/voluntary-repatriation.html (accessed July 12, 2018).

${ }^{47}$ Badil. Survey of Palestinian Refugees and Internally Displaced Persons (2008-2009).

${ }^{48}$ Sieghart, Paul. The International Law of Human Rights. Oxford: Oxford University Press, 1985. 174-178 
through International Covenant on Civil and Political Rights (1966) to be applied on individuals. Hence, the resolution asserted obvious legal right on individuals ${ }^{49}$.

The most important universal prerequisites are mentioned in International Covenant on Civil and Political Rights (1966). To state one of the vital examples we have mentioned the following point: 'no one shall be arbitrarily deprived of the right to enter his own country'. Simultaneously, we have to explore the answers to various questions. Which type of refugees have right to return or is there any close working relationship between state government and refugees? While discussing various texts from the literature on this matter and cast scholarly looks and deep visions, a comparative result is evolved accordingly. Eventually, we would be surprised to know that conclusion of such texts is summarized as follows: 'the right to return is probably reserved only for nationals of the state $^{50}$.

\section{Conclusion}

The Israeli perception of continued enmity with Palestinian refugees since 1948, has not changed and its functions are still the same today. Israeli authorities now completely apprehend the right to return of Palestinian refugees. They continuously stressed that displaced refugees or descendants must not be permitted to go back to their houses, keeping in mind the facts of the perception that their return would create an opportunity towards the protection of the tolerance in Jewish demographic majority in Israel. However, Palestinians continued to stand on this view point that right to return should be executed in justified manner in order to resolve their never-ending conflicts peacefully. Since the well-established political, monetary and army powers of Israel have full holding in the region and sets aside all incentives to deliver and/or stand accountable for its excesses and aggressions or inclined to make any compensations. Moreover, Israelis always on a move to propagate actively through its computing devices, just in an attempt to normalize the country's darkish history and its continuous, never ending and ongoing oppressions on Palestinians. In other words and to be more precise, their intentions are blended in repeated violations of human rights, along with ethnic and religious refining and various innumerable deficiencies, and try to become regularly involved in sensitive issues as an ordinary and common man, if reasonable sources and sufficient time are given. This self-invented manifesto of normalization has a significant impact on the perceptions of global audiences, Israeli public and even Palestine supporters who have turned out to be disheartened with the aid of the negative potentialities for a truthful resolution.

\footnotetext{
${ }^{49}$ Jagerskiold, Stig. "The Freedom of Movement ." In The International Bill of Rights, by Louis Henkin. New York, 1981, 180.

${ }^{50}$ Watson, Geoffrey R. The Oslo Accords: International Law and the Israeli-Palestinian Peace Agreements. (Oxford: Oxford University Press, 2000).
} 


\section{Bibliography}

AFSC. Palestinian refugees and the right of return. 2010. https://www.afsc.org/resource/palestinian-refugeesand-right-return (accessed December 6, 2018).

Alarby. Israel's destruction of Palestinian village is 'war crime': Amnesty. 2018.

https://www.alaraby.co.uk/english/news/2018/9/7/israels-destruction-of-palestinian-village-is-war-crimeamnesty (accessed December 7, 2018).

Badil. Survey of Palestinian Refugees and Internally Displaced Persons (2008-2009). July 12, 2009. https://www.badil.org/phocadownload/Badil_docs/publications/survey08-09/survey08-09-executivesummary.pdf (accessed 2018).

Badil. Survey of Palestinian Refugees and Internally Displaced Persons (2008-2009).

Boling, Gail J. Palestinian Refugees and the Right of Return: An International Law Analysis. 2001.

https://www.badil.org/phocadownload/Badil_docs/bulletins-and-briefs/Brief-No.8.pdf (accessed July 12, 2018).

Bracka. Past the Point of No Return? The Palestinian Right of Return in International Human Rights Law. 2005. https://law.unimelb.edu.au/_data/assets/pdf_file/0005/1681169/Bracka.pdf (accessed December 9, 2018).

Brynen, Rex. "Compensation for Palestinian Refugees: Law, Politics and Praxis." Israel Law Review 51, no. 1 (2018): 29-46.

Chen, Tianshe. "Palestinian Refugees in Arab Countries and Their Impacts." Journal of Middle Eastern and Islamic Studies (in Asia) 3, no. 3 (2009): 42-56.

Dowling, Paddy. Jordan's Palestinian refugee camps. 2018.

https://www.independent.co.uk/news/world/middle-east/jordan-palestine-refugee-camps-photographya8341826.html (accessed July 12, 2018).

Henri, Rueff, and Viaro Alain. Palestinian Refugee Camps: From Shelter to Habitat. 2010. http://doc.rero.ch/record/302490/files/hdp041.pdf (accessed July 12, 2018).

Jagerskiold, Stig. "The Freedom of Movement ." In The International Bill of Rights, by Louis Henkin. New York, 1981, 180.

John Cabot University. The Recognition of an Independent Palestinian State. 2012. https://www.johncabot.edu/...jcumun\%20general\%20assembly\%20study\%20guide.do (accessed December 9, 2018).

Kalman, Matthew. The Palestinian Right of Returnin in International Law - The Israeli Perspective. 2017. https://prrn.mcgill.ca/research/papers/matthewkalman.pdf (accessed December 5, 2018).

Kassim, Anis. F. "Legal Systems and Developments in Palestine." Palatine Yearbook of International Law 1, no. 1 (1984).

Khalidi, Walid. "Observations on the Right of Return.” Journal of Palestine Studies 21, no. 2 (1992)

Khalidi, Walid. "Plan Dalet: Master Plan for the Conquest of Palestine." The Journal of Palestine Studies 18, no. 1 (1988)

Khalidi, Walid. "Revisiting the UNGA Partition Resolution.” The Journal of Palestine Studies 27, no. 1 (1997)

Kramer, Tanya. "The Controversy of a Palestinian"Right of Return to Israel." Arizona Journal of International and Comparative Law 18, no. 3 (2001)

Lapidoth, Ruth. Legal Aspects of the Palestinian Refugee Question. 2002. http://www.jcpa.org/j1/vp485.htm (accessed July 12, 2018). 
Lawand, K. "The Right to Return of Palestinians in International Law." International Journal of Refugee Law 8, no. 4 (1996): 532-568.

OHCHR. International Convention on the Elimination of All Forms of Racial Discrimination. 1969. https://www.ohchr.org/en/professionalinterest/pages/cerd.aspx (accessed July 12, 2018).

OHCHR. Israeli settlements in the Occupied Palestinian Territory including East Jerusalem, and the occupied Syrian Golan. 2017. https://www.un.org/unispal/document/ga-resolution-on-israeli-settlements-in-the-occupiedpalestinian-territory-including-east-jerusalem-and-the-occupied-syrian-golan/ (accessed December 7, 2018).

Pappe, Ilan. The Ethnic Cleansing of Palestine. London: Oneworld Publication, 2006.

Peretz, Don. Palestinians, Refugees, and the Middle East Peace Process. Washington, D.C: US Institute of Peace Press, 1993.

Rempel, Terry M. The United Nations Conciliation Commission for Palestine, Protection, and a Durable Solution for Palestinian Refugees. 2000. http://badil.org/phocadownload/Badil_docs/bulletins-and-briefs/BriefNo.5.pdf (accessed July 12, 2018).

Sayej, Loureen. Palestinian Refugees and the Right of Return in International Law. 2018. http://ohrh.law.ox.ac.uk/palestinian-refugees-and-the-right-of-return-in-international-law/ (accessed December $8,2018)$

Security Council Report. Security Council Official Records. 1979. https://www.securitycouncilreport.org/wpcontent/uploads/Chap\%20VII\%20SPV\%202157.pdf (accessed December 7, 2018).

Sieghart, Paul. The International Law of Human Rights. Oxford: Oxford University Press, 1985. 174-178

Sirhan, Bassem. Palestinian Refugee Camp Life in Lebanon. 1974. http://www.palestinestudies.org/jps/fulltext/38366 (accessed July 12, 2018).

UNHCR. convention and Protocol relating to the Status of Refugees. 1967.

https://cms.emergency.unhcr.org/documents/1 1982/55726/Convention+relating+to+the+Status+of+Refugees+ $\% 28$ signed+28+July+1951\%2C+entered+into+force $+22+$ April $+1954 \% 29+189+$ UNTS+150+and+Protocol+rel ating+to+the+Status+of+Refugees+\%28signed+31+January+1967\%2C+ent (accessed July 12, 2018).

UNRWA. General Assembly Resolution 194. 2010. https://www.unrwa.org/who-we-are?tid=85 (accessed July $12,2018)$.

Watson, Geoffrey R. The Oslo Accords: International Law and the Israeli-Palestinian Peace Agreements. (Oxford: Oxford University Press, 2000).

Yin, Gang. Arab-Israeli Conflict: Problems and Way Out. Beijing: International Cultural Press, 2002. 309-310

Zonsheine, David. Israel is about to destroy this Palestinian village. Will Britain step in? 2018. https://www.theguardian.com/commentisfree/2018/jun/14/israel-destroy-palestinian-village-khan-alahmar (accessed December 23, 2018). 